\title{
金属アルコキシド法によるコーディエライトームライト複合 前駆体粉末の合成と焼結
}

\author{
鈴木久男・斎藤肇 \\ (豊田工業大学機械システム工学科, 468 名古屋市天白区久方 2-12-1)
}

\section{Preparation of Precursor Powders of Cordierite-Mullite Composites from Metal Alkoxides and Its Sintering}

\author{
Hisao SUZUKI and Hajime SAITO \\ (Department of Mechanical System Engineering, Toyota Technological Institute, \\ 2-12-1, Hisakata, Tenpaku-ku, Nagoya-shi 468
}

\begin{abstract}
Homogeneous precursor powders for obtaining cordierite composites with uniformly dispersed mullite particles were prepared by partial hydrolysis of alkoxides. The precursor powders crystallized into mullite and $\mathrm{MgAl}_{2} \mathrm{O}_{4}$ at $900^{\circ} \mathrm{C}$. Cordierite crystal was formed above $1200^{\circ} \mathrm{C}$, which was formed through the solid-solid reactions among $\mathrm{MgAl}_{2} \mathrm{O}_{4}, \beta$-quartz solid solution, sapphirine and unknown phases. The crystalline phases in the composites sintered above $1300^{\circ} \mathrm{C}$ were cordierite and mullite. The dense composite containing 40 mol\% mullite which was obtained by firing at $1300^{\circ} \mathrm{C}$ for $2 \mathrm{~h}$ had the mean 4-point bending strength of $125 \mathrm{MPa}$ and the thermal expansion coefficient of about $3.1 \times 10^{-6} /{ }^{\circ} \mathrm{C}$, respectively.
\end{abstract}

[Received December 23, 1987 ; Accepted February 23, 1988]

Key-words : Precursor powders, Cordierite, Mullite, Composite, Metal alkoxides

\section{1. 緒 言}

コーディエライト $\left(2 \mathrm{MgO} \cdot 2 \mathrm{Al}_{2} \mathrm{O}_{3} \cdot 5 \mathrm{SiO}_{2}\right)$ は耐熱 衝撃性, 耐熱性, 化学的安定性に優れた低熱膨張材料で ある．また，近年誘電率が低く絶縁性が高いため，高速 素子用 IC 基板材料として注目されている ${ }^{1)}$. しかし， 機械的強度が若干不十分であり ${ }^{2)}$ ，他の材料との複合に よる強化が望まれる.そして, ムライト $\left(3 \mathrm{Al}_{2} \mathrm{O}_{3} \cdot 2 \mathrm{SiO}_{2}\right)$ は IC 基板材料として最も良く用いられているアルミナ に近い強度を持ち ${ }^{3)}$, 電気的にはコーディエライトと良 く似た性質 (低誘電率, 高絶縁性) を有するため4), コ一 ディエライトとの複合材料として有望な材料である ${ }^{5)}$. 更に，ムライトは Siよりも熱膨張係数が高く ${ }^{6)}$, コー ディエライトと複合化することで複合焼結体の熱膨張係 数を制御することが可能であると思われる.

また, 高速素子用の IC 基板材料は導体として金, 銀, 銅等の電気抵抗の小さい材料を用いることが望まれるた め, 比較的低温で焼成する必要がある．著者ら ${ }^{7}$ は金属 アルコキシドの部分的加水分解法を用いて, $1200^{\circ}$ $1400^{\circ} \mathrm{C}$ の広い温度範囲で緻密なコーディエライト焼結 体が得られることを示した. 本研究においてもこの方法 を用い，比較的低温で緻密なコーディエライトームライ 卜複合焼結体を合成することを試みた。

\section{2. 実験方法}

図 1 に複合前駆体粉末の調製手順を示す。実験方法は
コーディエライト微粉体を調製する場合8)とほぼ同様で ある.そして，ムライト含有量により $\mathrm{SiO}_{2}$ 原料のケイ 酸エチルを所定量, 部分的に加水分解及び重合し（ケイ 酸エチルの部分的加水分解溶液), 一方 $\mathrm{Al}_{2} \mathrm{O}_{3}$ 原料のア ルミニウムイソプロポキシドは $\mathrm{Mg}-\mathrm{Al}$ ダブルアルコキ シド溶液中に所定量加え溶解した。 その後, 二液を混合 及び反応させて均一な前駆体溶液を調製した，溶液の濃 度はいずれの場合もアルコキシド濃度が $1 \mathrm{~mol} / 1$ となる ようにした．この前駆体溶液に，ケイ酸エチルに対しモ ル比で 20 倍の蒸留水を滴下して複合前駆体粉末とした.

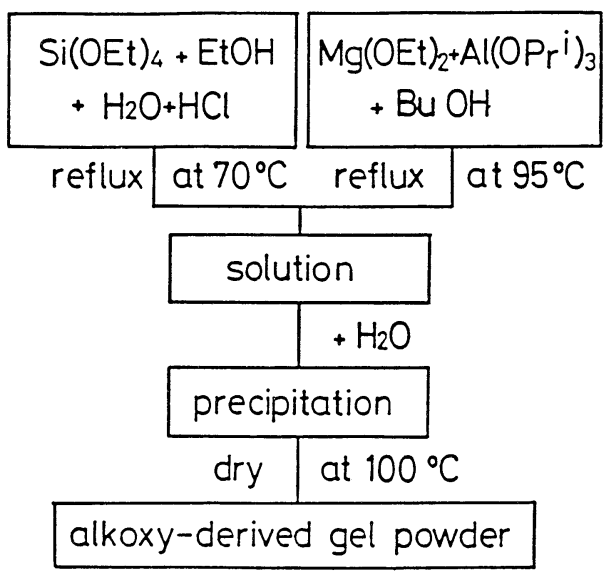

Fig. 1. Schematic diagram for the powder preparation of cordierite-mullite precursor. 
この非晶質粉体を乾燥, 仮焼した後に種々の方法で結晶


時間仮焼した後, 成形して $1300^{\circ} \sim 1450^{\circ} \mathrm{C}$ までの温度で 2 時間焼成した.焼結体の密度はアルキメデス法により, 強度は焼結体より約 $3 \times 4 \times 40 \mathrm{~mm}$ の試験片を切り出し, 研磨後, 4 点曲げ法により測定した. 熱膨張係数は石英 ガラスを標準試料とした差動型示差熱膨張計（理学電機 製，TMA）により測定した。測定試料の長さは $10 \mathrm{~mm}$ 以上のものを用い, 昇温速度は $5^{\circ} \mathrm{C} / \mathrm{min}$ とした。 ムラ イト含有量は 10～ $50 \mathrm{~mol} \%$ とし，10\% の場合は以下の 記述において M-10 と記すことにする.

\section{3. 結果と考察}

\section{1 コーディエライト及びムライトの結晶化過程}

表 1 に複合前駆体粉末を $900^{\circ} \sim 1450^{\circ} \mathrm{C}$ までの各温度 で 2 時間仮焼したときの結晶相を X 線回折により同定 した結果を示す.ムライト相はムライト単味 ${ }^{9)}$ の場合と 異なり，Al，Si-スピネルを経ることなく，比較的低温 で直接ムライト化する. そして, いずれの組成において も $900^{\circ} \mathrm{C}$ ではほぼ非晶質であるが，M-50 においてわず かにムライトと $\mathrm{MgAl}_{2} \mathrm{O}_{4}$ が認められ，この 2 相が初晶 として晶出すると思われる. $1000^{\circ} \mathrm{C}$ でいずれの組成に おいてもムライトと $\mathrm{MgAl}_{2} \mathrm{O}_{4}$ が同定され，ムライト含 有量の少ない M-10 と M-20では未知相 (X 線回折の ピークはシリカ $\mathrm{K}$ の角度とほぼ一致し,この未知相が 認められなくなる温度で $\beta$-クォーツ固溶体が晶出する ことから，その組成はシリカが主成分であると考えられ る）が晶出した. $1200^{\circ} \mathrm{C}$ ではムイト含有量が 30 $\mathrm{mol} \%$ 以下の $\mathrm{M}-10 \sim \mathrm{M}-30$ で $\beta$-クォーツ固溶体が同定 され，M-10 と M-20ではわずかに $\alpha$-コーディエライ 卜が認められた. $1300^{\circ} \mathrm{C}$ 以上でいずれの組成において も $\alpha$-コーディエライトが同定された.この温度で $\beta$ クォーツ固溶体は認められなかった。 また， $1200^{\circ} \mathrm{C}$ 以 上で同定された未知相は $1100^{\circ} \mathrm{C}$ ののとは異なってい た. $1400^{\circ} \mathrm{C}$ ではライト, サフィリン $(4 \mathrm{MgO} \cdot 5$ $\left.\mathrm{Al}_{2} \mathrm{O}_{3} \cdot 2 \mathrm{SiO}_{2}\right)$ 及び $\alpha$-コーディエライトのみが認められ た.そして, コーディエライトの融点に非常に近い $1450^{\circ} \mathrm{C}$ でムライトとコーディエライトのみとなった. これらのことから, 複合前駆体粉末の結晶化過程は次の ようであると推察される.

(1) $900^{\circ} \mathrm{C}$ 付近でのムライト及び $\mathrm{MgAl}_{2} \mathrm{O}_{4}$ の結晶 化.

(2) M-10 と $\mathrm{M}-20$ 組成における， $1000^{\circ} \mathrm{C}$ での $\mathrm{SiO}_{2}$ 成分に富んだ未知相の結晶化.

( 3 ） $1200^{\circ} \mathrm{C}$ でのサフィリン, $\beta$-クォーツ固溶体及 び別の未知相の結晶化.

(4) $1200^{\circ} \mathrm{C}$ 以上での $\mathrm{MgAl}_{2} \mathrm{O}_{4}, \beta$-クォーツ固溶体, サフィリン及び未知相の反応による $\alpha$-コーディエライ トの結晶化.

Sugiura と Kamigaito ${ }^{10)}$ は $\mathrm{MgAl}_{2}\left(\mathrm{i}-\mathrm{OC}_{3} \mathrm{H}_{7}\right)_{8}$ の加水 分解により, $\mathrm{MgAl}_{2} \mathrm{O}_{4}$ を合成したが, その際スピネル 相は $700^{\circ} \sim 800^{\circ} \mathrm{C}$ で結晶化することを報告した. した がって, 本研究においてもケイ酸エチルの部分的加水分 解溶液中に残存する水のため, $\mathrm{Mg}-\mathrm{Al}$ ダブルアルコキ シドが局部的に加水分解され, $\mathrm{MgAl}_{2} \mathrm{O}_{4}$ が初晶として 晶出したものと思われる. ムライト相がその化学量論組

Table 1. Crystalline phases of the calcined powders determined by X-ray diffraction.

\begin{tabular}{|c|c|c|c|c|c|c|c|}
\hline Temp. Comp. & $M-10$ & $M-20$ & $M-30$ & $M-40$ & $M-50$ & Cordierite & Mullite \\
\hline $900^{\circ} \mathrm{C} \times 2 \mathrm{~h}$ & - & - & - & - & $M, S$ & $\mathrm{Am}$ & - \\
\hline $1000^{\circ} \mathrm{C} \times 2 \mathrm{~h}$ & $\mathrm{M}, \mathrm{S}, \mathrm{UN} \mathrm{I}$ & $M, S$, UN 1 & $M, S$ & $M, S$ & $M, S$ & $\mu$ & $S^{\prime}$ \\
\hline $1100^{\circ} \mathrm{C} \times 2 \mathrm{~h}$ & $\mathrm{M}, \mathrm{S}, \mathrm{UN} \mathrm{I}$ & M, S, UN 1 & $M, S$ & $M, S$ & $M, S$ & $\mu, \alpha$ & $M, S^{\prime}$ \\
\hline $1200^{\circ} \mathrm{C} \times 2 \mathrm{~h}$ & $\begin{array}{l}M, S, S A P, \\
B Q, \alpha, U N 2\end{array}$ & $\begin{array}{l}M, S, S A P, \\
\beta Q, \alpha, U N 2\end{array}$ & $\begin{array}{l}M, S, S A P, \\
B Q, U N 2\end{array}$ & $\begin{array}{l}\text { M, S, SAP, } \\
\text { UN2 }\end{array}$ & $\begin{array}{l}\text { M, S, SAP, } \\
\text { UN } 2\end{array}$ & $\alpha$ & M \\
\hline $1300^{\circ} \mathrm{C} \times 2 \mathrm{~h}$ & $\begin{array}{l}\text { M, S, SAP, } \\
\alpha, \text { UN2 }\end{array}$ & $\begin{array}{l}\text { M, S, SAP, } \\
\alpha, \text { UN2 }\end{array}$ & $\begin{array}{l}M, S, S A P, \\
\alpha, U N 2\end{array}$ & $\begin{array}{l}\text { M,S, SAP, } \\
\alpha, \text { UN } 2\end{array}$ & $\begin{array}{l}M, S, S \text { AP, } \\
\alpha, \text { UN2 }\end{array}$ & $\alpha$ & M \\
\hline $1400^{\circ} \mathrm{C} \times 2 \mathrm{~h}$ & $M, S A P, \alpha$ & M, SAP, $\alpha$ & $M, S A P, \alpha$ & $M, S A P, \alpha$ & $M, S A P, \alpha$ & $\alpha$ & M \\
\hline $1450^{\circ} \mathrm{C} \times 2 \mathrm{~h}$ & $M, \alpha$ & $M, \alpha$ & $M, \alpha$ & $M, \alpha$ & $M, \alpha$ & - & $M$ \\
\hline
\end{tabular}

M;Mullite, S;Mg,Al-spinel, SAP;Sapphirine, S';Al,Si-spinel, BQ; $\beta$-quartz solid solution, $\mu ; \mu$-cordierite, $\alpha ; \alpha$-cordierite, Am;Amorphous, UN1;Unkown 1 , UN 2 ; Unkown 2

Table 2. Crystallization temperatures of cordierite and mullite determined by DTA.

\begin{tabular}{lrrrrrrr}
\hline Chase & $M-10$ & M-20 & M-30 & M-40 & M-50 & Cordierite & Mullite \\
\hline Mullite & $955^{\circ} \mathrm{C}$ & $955^{\circ} \mathrm{C}$ & $955^{\circ} \mathrm{C}$ & $945^{\circ} \mathrm{C}$ & $940{ }^{\circ} \mathrm{C}$ & - & $985^{\circ} \mathrm{C}$ \\
Cordierite & $1295{ }^{\circ} \mathrm{C}$ & $1300{ }^{\circ} \mathrm{C}$ & $1330{ }^{\circ} \mathrm{C}$ & $1330{ }^{\circ} \mathrm{C}$ & - & $1140{ }^{\circ} \mathrm{C}$ & - \\
\hline
\end{tabular}


成の前駆体溶液を加水分解した場合よりも低温で認めら れた理由は明らかでないが，スピネル相が先に結晶化し たことにより，核形成位置が増加した可能性が考えられ る.また，組成の影響もあると思われる．このことは， 後に得られた微粉体の格子定数の測定によっても裏付け られた。 $\alpha$-コーディエライトはムライト含有量が少ない ほど生成しやすいと考えられる。これは前駆体粉末の調 製方法に原因があると考えられる，すなわち，ケイ酸工 チルの部分的加水分解溶液と, $\mathrm{Mg}-\mathrm{Al}$ ダブルアルコキ シドとアルミニウムアルコキシドの混合溶液を混合した 際, ケイ酸エチルの部分的加水分解溶液中にかなりの水 が残存しており，これが優先的に $\mathrm{Mg}-\mathrm{Al}$ ダブルアルコ キシドを加水分解するためと思われる.そして, コーディ エライトはコーディエライトのみの前駆体溶液を加水分 解した場合 ${ }^{8)}$ のうに $\mu$-コーディエライトが生成し, 次 いで $\mu$-コーディエライトが $\alpha$-コーディエライトに転移 するのではなく, $\mathrm{SiO}_{2}$ 成分に富んだ末知相あるいはガ ラス相と $\mathrm{MgAl}_{2} \mathrm{O}_{4}, \beta$-クォーツ固溶体及びサフィリン との固相反応により $\alpha$-コーディエライトが生成するも のと思われる. これは各アルコキシドの混合溶液を加水 分解した場合のコーディエライトの生成過程 ${ }^{8)}$ 之, 本研 究で得られた複合前駆体を仮焼したときの結晶相が類似 していることからも予想される. 一方，ムライトの前駆 体は, $\mathrm{Mg}-\mathrm{Al}$ ダブルアルコキシドが残留する水と先に 反応してしまうため， $\mathrm{Al}$ のアルコキシドのみが選択的 に加水分解されることはなく, 溶液中で比較的均一に生 成していると思われる.

表 2 にムライトとコーディエライトの結晶化温度を示 差熱分析 (DTA) により測定した結果を示す.ムライ トの結晶化温度は, 不均質性が増すと予想されるムライ ト含有量の増加に伴い低温側にシフトした。一方, コー ディエライトの結晶化温度はムライト含有量の増加に伴 い高温側にシフトする傾向にあった.これらの事実も上 述の結論を支持するものである.

表 3 に $\mathrm{M}-30$ 組成の複合前駆体粉末の仮焼による比表 面積の変化を示す. 比表面積の変化は, コーディエライ ト単味の場合 ${ }^{7)}$ とほぼ同様である. 複合前駆体の比表面 積は, $800^{\circ} \mathrm{C}$ では非常に大きく, $900^{\circ} \mathrm{C}$ 以上で急激に減

Table 3. Specific surface areas of the calcined powders.

\begin{tabular}{cc}
\hline Calcination temperature $\left({ }^{\circ} \mathrm{C}\right)$ & Specific surface area $\left(\mathrm{m}^{2} / \mathrm{g}\right)$ \\
\hline $800^{\circ} \mathrm{C} \times 2 \mathrm{~h}$ & 425 \\
$900^{\circ} \mathrm{C} \times 2 \mathrm{~h}$ & 24 \\
$1000^{\circ} \mathrm{C} \times 2 \mathrm{~h}$ & 11 \\
$1100^{\circ} \mathrm{C} \times 2 \mathrm{~h}$ & 6.0 \\
$1200^{\circ} \mathrm{C} \times 2 \mathrm{~h}$ & 1.4 \\
$1300^{\circ} \mathrm{C} \times 2 \mathrm{~h}$ & 4.4 \\
$1400^{\circ} \mathrm{C} \times 2 \mathrm{~h}$ & 2.3 \\
$1450^{\circ} \mathrm{C} \times 2 \mathrm{~h}$ & 0.8 \\
\hline
\end{tabular}

少する. しかしながら，ムライト相は高温で仮焼しても 粒成長しにくいことから ${ }^{9)}, 900^{\circ} \mathrm{C}$ 以上ではコーディエ ライト粉体の比表面積よりも大きかった。 そして，比表 面積は $1200^{\circ} \mathrm{C}$ まで減少した後, $1300^{\circ} \mathrm{C}$ でわずかに増 加した.これは $\alpha$-コーデイエライトが多量に晶出した ためと思われる. すなわち， $\alpha$-コーディエライトが結晶 化する際に体積の膨張を伴うため, 微粉体中に亀裂が生 じ，比表面積が増加したと考えられる. $1300^{\circ} \mathrm{C}$ 以上の 温度で仮焼すると, 再び比表面積は減少した. $1450^{\circ} \mathrm{C}$ ではコーディエライトの溶融温度に非常に近いため, 著 しい粒成長が起こるものと考えられる.

\section{2 格子定数}

晶出したムライトとコーディエライトの格子定数を粉 末 X 線回折法により測定した結果を，それぞれ図 2 と 図 3 に示す. ムライトの格子定数はいずれの温度でも化 学量論値から大きくずれることはないが，ムライト含有 量が多い組成のものほど JCPDS 15-776の值に近付く 傾向がある. また, 仮焼温度が高くなると, $a_{0}$ 軸と $c_{0}$ 軸は増加し, $b_{0}$ 軸は減少する傾向にある ${ }^{11)}$. これは低 温では化学量論値よりも $\mathrm{SiO}_{2}$ 成分に富むムライトであ り, 温度の上昇とともにガラス相と化学量論組成に近い ムライトが生成することを示唆している.一方, コーディ エライトの格子定数は組成に対して敏感であるが, 本研 究で得られた複合粉体中のコーディエライトの格子定数 は, 温度によらず $a_{0}$ 軸, $c_{0}$ 軸ともに, いずれの組成に

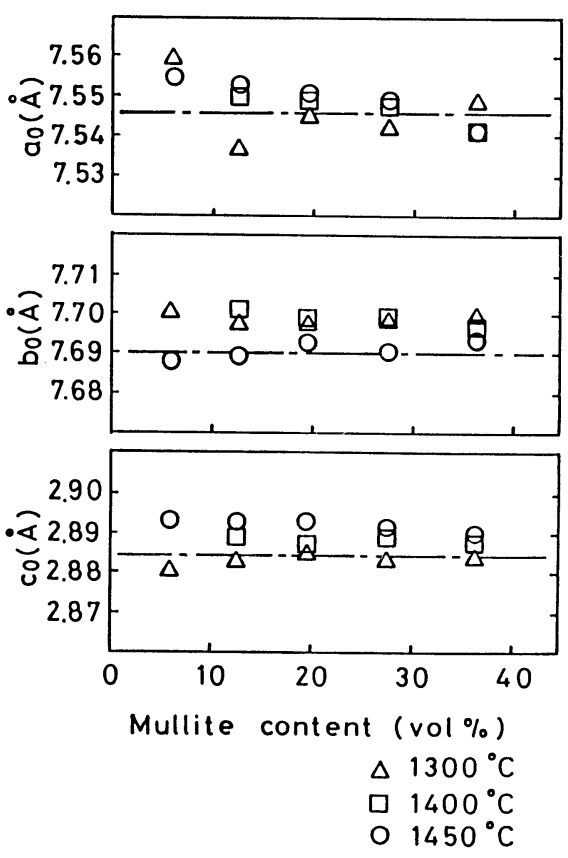

Fig. 2. Change in the lattice parameters of mullite in the composite powders with calcination temperatures. Chain lines represent the values reported in JCPDS 15-776. 
おいても化学量論値やコーディエライト単味で調製した 場合の值 ${ }^{8)}$ からなりずれていた。 また, 晶出したコー ディエライトの格子定数は, ムライト含有量が多くなる ほど化学量論值からずれて行く傾向にあり, 複合粉体の 組成によってコーディエライトの組成が変化していると 思われる.これらは, $\mathrm{MgAl}_{2} \mathrm{O}_{4}$ とサフィリン, $\beta$-クォー ツ固溶体, 未知相及びガラス相の固相反応によりコー ディエライトが晶出したことを裏付けている.

\section{3 曲げ強度}

$1300^{\circ}, 1400^{\circ}$ 及び $1450^{\circ} \mathrm{C}$ で 2 時間焼成して得られた 焼結体の相対密度と曲げ強度を, それぞれ図 4 と図 5 に 示す. 焼結体を粉砕し, X 線回折により結晶相を調べ たところ, いずれの焼結体においてもコーディエライト とムライトのみであった. したがって, 焼結体の相対密 度はコーディエライトとムライトのみと仮定し, その組 成から計算により求めた。焼結体の密度はいずれの焼成 温度でも $95 \%$ 前後であり, $1300^{\circ} \mathrm{C}$ の焼成では何れの組 成においても $96 \%$ 以上の緻密な焼結体が得られた。

Mussler と Shafer ${ }^{5)}$ はあらかじめ合成したムライトと コーディエライト組成のガラスから複合体を作製し， $1455^{\circ} \mathrm{C}$ 以下の焼成では理論密度の $75 \%$ 以上の焼結体は 得られなかったと報告している. また, 井川ら ${ }^{12)}$ は酸化 アルミニウム, 水酸化マグネシウム及び無水ケイ酸を $1000^{\circ} \mathrm{C}$ で仮焼した後, 更に $1400^{\circ} \mathrm{C}$ で 20 時間仮焼した 粉体を $1450^{\circ} \mathrm{C}$ で焼成することで相対密度が $94 \%$ 以上の
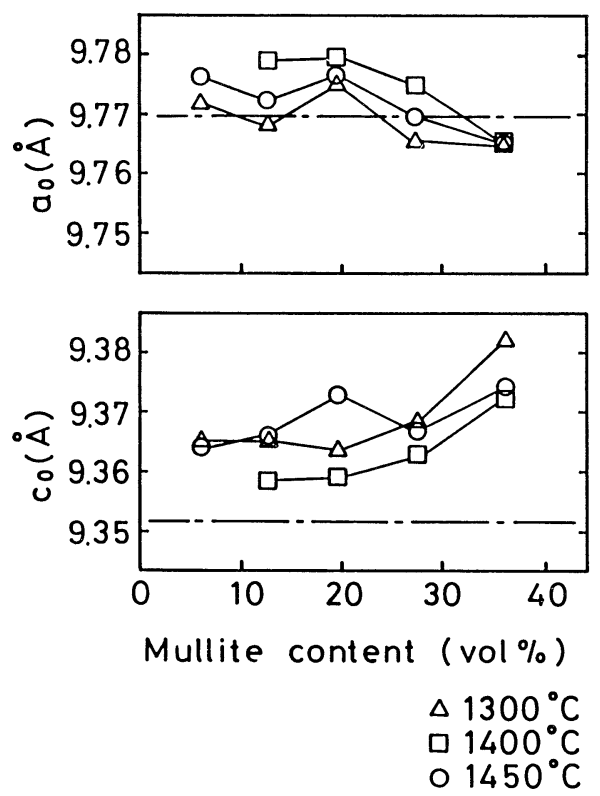

Fig. 3. Change in the lattice parameters of cordierite in the composite powders with calcination temperatures.

Chain lines represent the values reported in JCPDS 13-293.
焼結体を得ている. 図 6 に焼結体の破断面の走査型電子 顕微鏡 $(S E M)$ 写真を示したが, 本研究で得られた複 合前駆体粉末を仮焼した後に焼成することで，1300 $1450^{\circ} \mathrm{C}$ の広い温度範囲で緻密なコーディエライトーム ライト複合焼結体が得られ（図 $6(\mathrm{a}),(\mathrm{b}))$, 金属アル コキシド法で調製した複合前駆体粉末の焼結性が非常に 優れていることが分かる.これは，均質な非晶質粉体の 持つ高い自由エネルギー ${ }^{13)}$ を緻密化に利用することが可 能であるためと思われる.

焼結体の曲げ強度は組成, 焼成温度等による一定の関 係は得られなかった. $1300^{\circ} \mathrm{C}$ で焼成した焼結体の曲げ

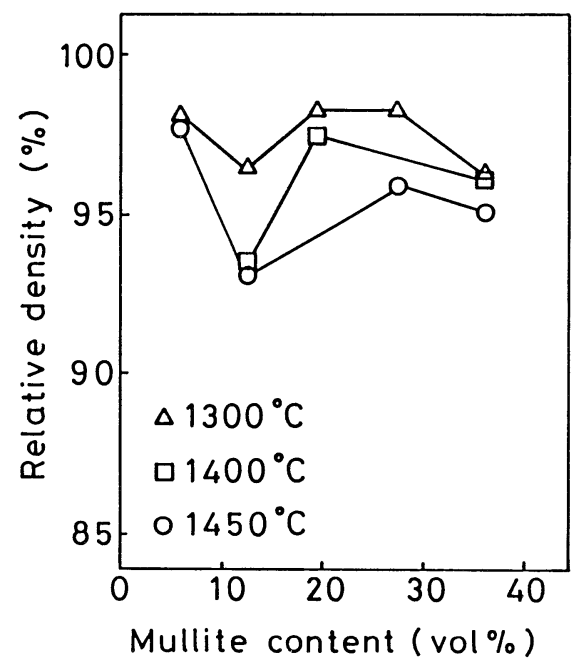

Fig. 4. Relative densities of the sintered compacts.

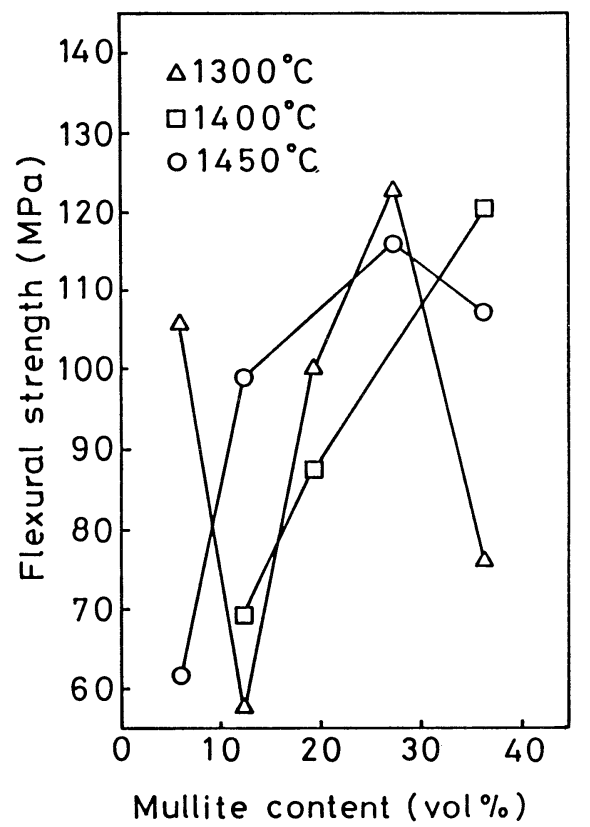

Fig.5. Flexural strengths of the sintered compacts. 
強度は, M-20 と M-50 組成以外では $100 \mathrm{MPa}$ 以上の 值を示した。をして、M-40 組成で平均曲げ強度の最高 值（125 MPa）を示した。この值は純粋なコーディエ

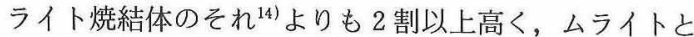
の複合により高強度となったものと思われる，M-20 と M-50 組成で低強度となった理由は明かではないが,
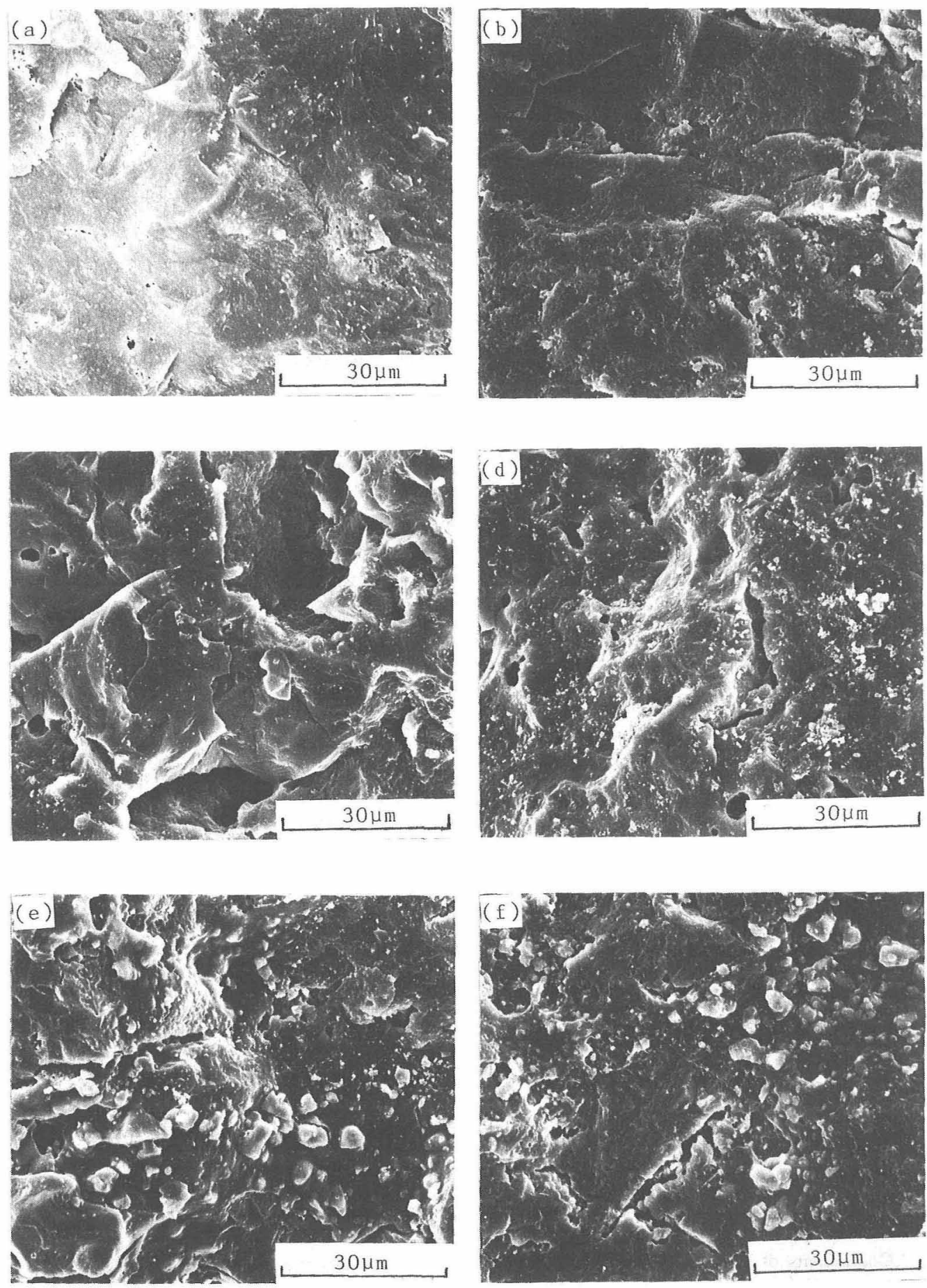

Fig. 6. SEM micrographs of the fractured surfaces of the sintered compacts.

(a) $\mathrm{M}-40$ sintered at $1300^{\circ} \mathrm{C}$, (b ) $\mathrm{M}-50$ sintered at $1400^{\circ} \mathrm{C}$, (c) $\mathrm{M}-10$ sintered at $1450^{\circ} \mathrm{C}$, (d) $\mathrm{M}-20$ sintered at $1450^{\circ} \mathrm{C}$, (e ) $\mathrm{M}-40$ sintered at $1450^{\circ} \mathrm{C}$, ( f ) $\mathrm{M}-50$ sintered at $1450^{\circ} \mathrm{C}$ 
M-50 組成ではムライトとコーディエライトの熱膨張係 数の差による゙焼結体中の残留応力が考えられる. $1400^{\circ} \mathrm{C}$ ではムライト含有量が少ないほど強度が低く なっており，コーディエライトマトリックスの軟化によ る気孔或は亀裂の発生の可能性が高い ${ }^{14)}$. そして，ムラ イト含有量が多い組成となるとともに, 高強度となった (M-50 組成で約 $120 \mathrm{MPa}) .1450^{\circ} \mathrm{C}$ においては, 部分 的な溶融によりガラス相がある程度生成していると思わ れ（図 $6(\mathrm{e}),(\mathrm{f}))$, これにより一度生成した気孔或は 亀裂が次第に小さくなり, ムライトの含有量とともに高 強度となったと考えられる. また, 前駆体粉末を仮焼し た場合のコーディエライトの格子定数の測定（図 3 ）か ら，いずれの焼成温度においてもガラス相は存在するも のと思われる. そして, $1450^{\circ} \mathrm{C}$ 焼成においてはムライ 卜含有量の増加とともに, 気孔や亀裂の大きさや量が減 少して行き（図 6 (c)〜 (f)), M-40 と M-50 組成では 2 $\sim 3 \mu \mathrm{m}$ あるいはそれ以下のムライト微粒子が焼結体中 に均一に分散している様子が観察され（図6 (e), (f)), 生成したムライト相により強化されて行く様子がわか る. M-50 組成での強度の低下は, $1300^{\circ} \mathrm{C} て ゙$ 焼成した 焼結体と同様の理由が考えられる.

\section{4 焼結体の熱膨張係数}

$1300^{\circ}$ と $1450^{\circ} \mathrm{C}$ で焼成した焼結体の，室温から $800^{\circ} \mathrm{C}$ までの平均熱膨張係数を図 7 に示す．焼結体の結晶相は 組成や焼成温度によらず，コーディエライトとムライト であったが，前駆体粉末を仮焼したときのコーディエラ イトとムライトの格子定数の測定から（図 2 と 3 ), い ずれの焼結体中にもガラス相が存在すると考えられる. したがって, 焼結体の熱膨張係数はこれらの相(コーディ エライト，ムライト及びガラス相）の相対量によって決 定されると思われる。 $1300^{\circ} \mathrm{C}$ で焼成した場合（図 7 の

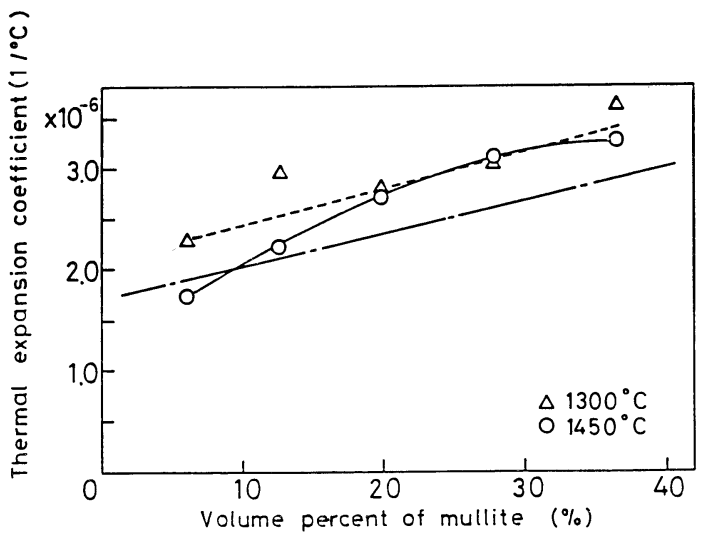

Fig. 7. Coefficients of thermal expansion of the sintered compacts. Solid and broken lines represent the values of the compacts sintered at $1450^{\circ}$ and $1300^{\circ} \mathrm{C}$, respectively. Chain line shows the value calculated from the composition.
破線)，M-20 組成を除いて膨張係数はほぼ直線的に増 加することから，M-20 以外の焼結体のガラス相の量は ほぼ同じくらいであると思われる，このことは, 図 7 の 破線の傾きと焼結体の組成から単純な複合則により求め た膨張係数の值（図 7 の 1 点鎖線）とがほぼ同じ傾きを 持つことからも推測される. そして, 最も高強度となっ た M-40 組成の焼結体の平均熱膨張係数は約 $3.1 \times 10^{-}$ ${ }^{6} /{ }^{\circ} \mathrm{C}$ であり, Si のそれ $\left(3.5 \times 10^{-6} /{ }^{\circ} \mathrm{C}\right)$ と非常に近い ことが分かった. $1450^{\circ} \mathrm{C}$ で焼成した場合 (図 7 の実線)， 同様にガラス相は存在すると考えられるが，ムライトの 含有量が少ない場合にはマイクロクラックなどの影響に より, 焼結体の膨張係数が小さくなったものと思われる. このことは, 焼結体の強度がムライト含有量の減少とと もに低くなり，M-10 組成ではコーディエライト単味の

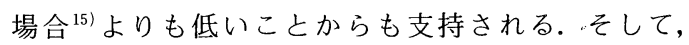
$1450^{\circ} \mathrm{C}$ での焼成では $\mathrm{M}-40$ と $\mathrm{M}-50$ 組成の焼結体の膨 張係数はそれぞれ, 3.1 及び $3.3 \times 10^{-6} /{ }^{\circ} \mathrm{C}$ であり, 比較 的高強度かつ Si に近い熱膨張係数の焼結体が得られる ことが分かった。

\section{4. 総 括}

金属アルコキシド法を用いて，比較的均質なコーディ エライトームライト複合前駆体粉末を調製した．この前 駆体を仮焼して，コーディエライト及びムライトの生成 過程を調べた結果, 以下の結論が得られた.

（1） $900^{\circ} \mathrm{C}$ 付近で，初晶としてムライトと $\mathrm{Mg}_{2} \mathrm{AlO}_{4}$ が晶出する.

（2）コーディエライトは $1200^{\circ} \mathrm{C}$ 以上の仮焼により 生成する.

（3）コーディエライトは $\mathrm{Mg}_{2} \mathrm{AlO}_{4}, \beta$-クォーツ固 溶体, サフィリン, 未知相及びガラス相の固相反応によ り生成する.

（4）晶出したムライトの格子定数は化学量論値に近 いものであるが，コーディエライトの格子定数はムライ 卜含有量の増加とともに化学量論値より大きくなる傾向 にある。

また，このようにして得られた前駆体粉末を $800^{\circ} \mathrm{C}$ で 12 時間仮焼した後に成形し，焼成して得られた焼結 体の性質を調べた結果，以下のことが分かった。

（1） $1300^{\circ} \mathrm{C}$ 以上で焼成して得られた焼結体の結晶 相は，組成や焼成温度によらず，いずれもコーディエラ イトとムライトのみである.

（2）得られた焼結体の相対密度はいずれも $95 \%$ 前 後であり，比較的緻密である．また，いずれの焼結体も ガラス相が残存すると思われる.

（3）焼結体の破断面の観察より，微細なムライト相 が均一に分散したコーディエライトームライト複合焼結 体が $1300^{\circ} \sim 1450^{\circ} \mathrm{C}$ の広い温度範囲で得られる. 
（4）ムライトとの複合により，コーディエライト単 味の焼結体よりも高強度, かつ熱膨張係数が Si に近い 焼結体が得られる.

\section{文献}

1) D. R. Bridge, D. Holland and P.W. McMillan, Glass Technology, 26, 286-92 (1985).

2) R. Morrell, Proc. Br. Ceram. Soc., 28, 53-71 (1979).

3) S. Kanazaki, T. Kumazawa, J. Asaumi, O. Abe and H. Tabata, Yogyo-Kyokai-Shi, 93, 407-08 (1985).

4）神崎修三，栗原 孝，岩井昇一，大橋優喜，田端英世, 窯協, 95, 1213-18 (1987).

5) B.H. Mussler and M.W. Shafer, Am. Ceram. Soc. Bull., 63, 705-14 (1984).
6) B. L. Metcalfe and J.H. Sant, Trans. Br. Ceram. Soc., 74, 193-201 (1975).

7) H. Suzuki, K. Ota and H. Saito, Yogyo-Kyokai-Shi, 95, 170-75 (1987).

8) idem., ibid., 95, 163-69 (1987).

9）鈴木久男，斎藤 肇，窯協，95，697-702 (1987).

10) M. Sugiura and O. Kamigaito, Yogyo-Kyokai-Shi, 92, 605-10 (1984).

11) W.E. Cameron, Am. Miner., 62, 745-55 (1977).

12）井川博行, 渡辺俊也, 浦部和順, 宇田川重和, 窯協, 93, 762-67 (1985).

13) R. Roy, J.Am. Ceram. Soc., 52, 344 (1969).

14) H. Suzuki, K. Ota and H. Saito, to be published in $J$. Mater. Sci.

15）斎藤 肇・鈴木久男・太田和秀，窯業協会昭和 61 年年会 講演予稿集, 2 F 08 (1985). 